\title{
The Implementation Of Act No. 42 Of 1999 On The Agreement Associated Fiduciary Guarantee Made By The Notary In Kudus
}

\author{
Febriyan Budi Santoso ${ }^{1}$, Mohamad Rofiqi ${ }^{2}$ and Gunarto ${ }^{3}$
}

Abstract. The purpose of this study (1) To analyze whether the fiduciary Agreement of Notary in Kudus which implemented the Act No.42 Of 1999 on Fiduciary (2) to analyze What barriers and solutions for Notary in Kudus in practicing the implementation of a credit agreement with fiduciary Agreement he made. Juridical approach method performed empirically, that is an approach which is conducted to analyze the extent to which a rule of law or the law being applied effectively. ${ }^{4}$ Discussion of the results showed that (1) fiduciary Agreement of Notary in Kudus what is already implementing Act No.42 Of 1999 on Fiduciary (2) barriers and solutions for Notary in Kudus in practice the implementation of a credit agreement with a fiduciary warranty Agreement made.

Keywords: Notary Agreement; Implementation; Agreement of Fiduciary.

\section{Introduction}

Economic development is placed on the main target with the aim to achieve a balance between agriculture and industry as well as the fulfillment of people's basic needs, which means that most of the development work is directed at economic development, while development in other areas is to support and supplement economics.

Economic development, as part of national development is an effort to reach a just and prosperous society based on Pancasila and the Constitution of 1945 . In order to maintain and carry forward the sustainable development, development actors both government and society, both individuals and legal entities in need of funds big. Along with the increasing development, so did the need for funding, most of the funds needed to meet these needs is obtained through borrowing. ${ }^{5}$

Obtaining of funding is one of them is through banking services, through loans granted by the Bank or through the services of other financial institutions. Credit facilities under construction is an absolute, because the credit is the lifeblood of the lives of the entrepreneurs. $^{6}$

\footnotetext{
${ }^{1}$ Student of Master Program (S2) of Notaries Faculty of Law Universitas Islam Sultan Agung email: febriyanbudisantoso@gmail.com

2 Students of Master of Law, Faculty of Law, Universitas Islam Sultan Agung email mohammadrofiqi26@gmail.com

${ }^{3}$ Profesor of Faculty of Law UNISSULA

${ }^{4}$ Soerjono Soekamto 1982 Pengantar Penelitian Hukum UI Jakarta Page 52

${ }^{5}$ Patrik Purwahid and Kashadi 2009 Hukum Jaminan Semarang BP Undip p.171.

${ }^{6}$ Djuhaenah Hasan 1996 Lembaga Jaminan Kebendaan Bagi Tanah dan Benda Lain Yang

Melekat Pada Tanah Dalam Konsepsi Penerapan Asas Pemisahan Horizontal (Suatu Konsep

Dalam Menyongsong Lahirnya Lembaga Hak Tanggungan) (Bandung: Citra Aditya Bakti) p. 6.
} 
To support fairness economic equality society, the government has also taken the discretion to modify and enhance the Articles of Act No. 7 of 1992 concerning Banking with enacted Act No.10 of 1998 on the Amendment of Act No. 7 of 1992 concerning Banking (Banking Law). While the rules for financial institutions other than banks, for example leasing (Lease) stipulated in Presidential Decree No. 9 of 2009 on Financing Institutions.

Banks have a role that is very important and decisive in the attainment of national goals, especially in accordance with the primary function of banks is a vehicle that can raise and channel public funds effectively and efficiently, based on economic democracy to support the implementation of national development in order to improve the distribution of development, growth economy and national stability towards improving the living standard of the people.

Banking institutions is at the core of the financial system of each country. Bank is a financial institution that is a place for individual, private business entities, bodies of state-owned enterprises, government agencies even keep its funds. Through the activities of credit and various services rendered, serving the needs of bank financing and launch the mechanism of payment systems for all sectors of the economy. ${ }^{7}$ In accordance with the bank function, namely as an intermediary (intermediary) between the parties that the excess funds to the cash-strapped, the funds raised by the bank should be channeled back to the community in the form of credit or loans to the public. $^{8}$

In practice, the loan portfolio is always preceded by a credit agreement or agreements made payable in written form between the banks as creditors and customers as the debtor or so-called credit agreement. Their accounts payable agreement was made with the aim that all the interests of the parties in the agreement guaranteed legal certainty.Agreement under the provisions of Article 1313 of the Civil Code, is defined as follows: "The agreement is an act by which one or more persons bind himself to one or more other people".

Noting the provisions of Article 1313 of the Civil Code mentioned above, it is implied that the real birth of a treaty obligation or achievement of one or more person (party) to one or more persons (the) others, who are entitled to these achievements. ${ }^{9}$ The formulation of that article provides that the legal consequences of a treaty there will always be two parties, where one party is the party required to perform (debtor) and the other party is the party entitled to the achievement (creditors). Terms valid an agreement which has been determined by law, so as to have binding legal force under Article 1320 of Law Book of the Civil Code, which consists of four conditions: a. The existence of an agreement they bind themselves; b). Ability to make a deal; c). A certain thing; $d$. One reason kosher.

Based on the above description can be formulated problems of the Is fiduciary Agreement of Notary in Kudus district has implemented the Act No.42 Of 1999 on

\footnotetext{
${ }^{7}$ Hermansyah 2006 Hukum Perbankan Nasional Indonesia Prenada Media Group Jakarta p 7.

8 Malay SP Hasibuan 2006 Dasar-dasar Perbankan Bumi Pustaka Jakarta p 3.

${ }^{9}$ Gunawan Widjaja and Ahmad Yani 2003 Jaminan Fidusia PT. Rajawali Press Jakarta p 13.
} 
Fiduciary? What barriers and solutions for Notary in Kudus in practice the implementation of a credit agreement with a fiduciary warranty Agreement make?

\section{Research Methods}

The method used is empirical juridical approach. Specifications of this research is descriptive. In the method of determining the sample used is purposive sampling data required in this discussion are the primary data and secondary data.Data analysis techniques are used in qualitative analysis.

\section{Result And Discussion}

\subsection{Is fiduciary Agreement of Notary in Kudus has implemented the Act No.42 Of 1999 on Fiduciary?}

The agreement itself is essentially composed of two forms of the agreement before a Notary or in notary Agreement that is authentic and not an agreement made before a Notary or agreement under hand. Regarding the authentic Agreement of agreement under Article 1868 of the Civil Code which states that a certificate is authentic agreement is an agreement made in the form prescribed by law by or made in the presence of public servants in power to it and at the place where the agreement was made. As is the Agreement of agreement under the hand is the Agreement of agreement that is made between the two parties without the involvement of a notary officials / authorities to it. ${ }^{10}$

The competent authorities make authentic act is the Notary, this is in accordance with the provisions of Article 1 paragraph 1 of the Act of the Republic of Indonesia Number 2 Of 2014 concerning the Amendment to Act No. 30 Of 2004 regarding Notary stating that the notary is a public official authorized to create an authentic Agreement and other authorities referred to in this Act.

It was also stated in Article 15 paragraph (1) of the Constitution of the Republic of Indonesia Number 2 of 2014 concerning the Amendment to Act No. 30 Of 2004 concerning Notary, that Notary authorized to make Agreement authentic on all Agreements, agreements, and determination required by legislation and / or desired by the stakeholders to be stated in the Agreement authentic, Guaranteeing the creation date of the Agreement, save Agreement, giving grosse, copy and quote Agreement, all of it along the Agreement of making it not also be assigned or excluded to other officials or any other person specified by law. Thus it can be the sense that the Notary is also authorized to make the Agreement of credit agreement.

Then the meaning of the Credit Agreement is the provision of credit agreement between the lender and the loan recipients ". Each loan has been approved and agreed between the lender and the loan recipient shall be set in the form of a credit agreement. The credit agreement itself can be made in the form of underhand or an

${ }^{10}$ Rini Pamungkasih 2009101 Draf Surat Perjanjian Mediatama Yogyakarta p 15. 
authentic Agreement notarized. Article 1313 Book of Civil Law (Civil Code) states the agreement is an act by which one or more persons bind himself to one or more other people.The credit agreement according to the Civil Code of Indonesia, is one of the forms of borrowing agreements. In any form of credit is substantially held is as a borrowing agreement as stipulated in the Civil Code, Article 1754 to Article 1769.

The credit agreement between the creditor and the debtor is a principal agreement, the credit agreement was able to bind both parties but does not have the power executorial. Lending and borrowing activities with the use of mortgageor guaranteed rights have been regulated in the Act No. 2 of 1996 on Mortgage on land. In addition, the security interest that is widely used by the notary to make the Agreement which is accesoir or additions are fiduciary.

In Indonesia alone, Fiduciary has been used since the Dutch colonial era as a form of collateral based Arrest hoggerechtshof born August 18, 1932 (BPM-Clynet Arrest). Arrest the birth of this because of the influence of the concordance. The birth of this Arrest influenced by the urgent needs of small entrepreneurs, retailers, traders and wholesalers medium that requires a credit facility for its business. ${ }^{11}$

To meet people's needs are constantly evolving and in order to create a statutory laws and regulations are complete and comprehensive that are not based on the jurisprudence again, it gives birth to the Law of the Republic of Indonesia Number 42 Of 1999 regarding Fiduciary. Law was born intended for the public about the legal basis for the norm of fiduciary as a means to aid legal certainty for the perpetrators of the business activities.

Fiduciary insurance provides convenience for the parties to use it, especially for those who provide fiduciary that is a bank or debtor. Based on Act No.42 Of 1999 regarding Fiduciary Article 5 (1) states that any imposition on the object with the fiduciary guarantee must be made by notarial Agreement in Indonesian and is a Fiduciary Agreement. Further described in Articles 11 and 12 to mention that moving objects that impose fiduciary, must be registered at the registration office fiduciary.

The provisions of Act No.42 of 1999 specifies that any agreement made with the required fiduciary authentic Agreement notarized and must be registered. Fiduciary warranty Agreement is a Agreement supplemental or accesoir, where jamianan fiduciary Agreement would exist if no Agreement of agreement that is essentially a loan agreement itself. Fiduciary warranty Agreement is a Agreement is a Agreement Partij ten overstaan made before a Notary, the Notary means read and witnessed the signing is done dihadapanya. Article 16 (1) clause 1 UUJN that:

"Reading the Agreement before penghadap in the presence of at least two (2) witnesses and signed on the spot by penghadap, witnesses and Notary".

While the Agreement of fiduciary who is already known as the Agreement of a million people, because of the Agreement in one day, it could be the making of the Agreement

\footnotetext{
${ }^{11} \mathrm{H}$. Salim HS 2007 Perkembangan Hukum Jaminan Di Indonesia Jakarta: Raja Grafindo Persada p. 60.
} 
by the notary in the district of Kudus not implement Act No.42 of 1999 on Fiduciary Article 16 (1) letter 1 above.

The problems that arise from the usual examples Agreement is not signed before a notary public is a fiduciary warranty Agreement. The number of fiduciary Agreement made by a Notary in the same time, there will be problems kedepanya. ${ }^{12}$ Practice habits binding Agreement is done outside the Notary's office at the same time in different places, Notary difficult to be in two different places in one time of signing the Agreement. UUJN affirmed in Article 44 paragraph (1) states that:

"As soon as the Agreement was read, the Agreement was signed by every penghadap, witnesses and Notary unless there penghadap you can not put his hand by mentioning the reason"

This fiduciary warranty Agreement future could cause legal problems related to the strength of evidence Agreement made by the Notary Public. Fiduciary Agreement shall be made in addition to the authentic, this certificate also must be registered. The legal basis of the registration of fiduciary Agreement stipulated in Chapter III of Part Two of Act No. 42 Of 1999 regarding Fiduciary Article 11 (1) "object encumbered with a fiduciary must be registered". Meaning of registration fiduciary object is to get a certificate of fiduciary has irah-irah "By Justice Based on God" who has the power executorial.

Consumer Financing Agreement with Delivery Properties In Fiduciary, mostly happens in practice is the agreement made in the form of a hand below. The credit agreement between creditors and debtors is made under the hand because there is no rule which provides that a credit agreement must be made in an authentic Agreement. Hand under the agreement between creditors and debtors is intended to gain efficiencies in expenses, manpower and time. Debtors can only be accept or not accept at all, which is likely to make changes nothing at all. In other words, the debtor must submit and adhere to the provisions contained in the credit agreement under the arm.

Thus, of matters relating to the shape of the above agreement, that the general credit agreement (the principal) is appropriate or not contrary to the provisions of Article 1338 of the Civil Code, on the principle of freedom of contract, and the agreement has to comply with Article 1320 of the Civil Code of the terms of the validity of the agreement. On the other hand, the financing agreement was made in the form of a Agreement under the hand contrary to the provisions of Article 6 paragraph a of Act No. 42 Of 1999 regarding Fiduciary, which states that the imposition (Agreement) fiduciary must be made in the form of an authentic Agreement, while the financing agreement in above, performed by the Agreement under the hand (because it is made not in the form of a notarial Agreement), sehngga the agreement has the disadvantage that is not protected by law from Law Fiduciary. Then the contents of the Consumer Financing Agreement with Delivery Properties In Fiduciary, already contain standard terms as a condition of validity of the agreement is based on the provisions of the

\footnotetext{
${ }^{12}$ Afandi Notary in Kudus personal interview dated 30-06-2018
} 
Code Article 1320 Civil Code as a requirement that the consumer financing agreement is valid under the law.

Banks that can bind to the binding fiduciary notary in Kudus district must also consider the requirements and rules of the authentic act in the form of a fiduciary warranty Agreement. This Agreement is a notary Agreement that has authenticity because it is made in accordance with the rule of law. Fiduciary warranty Agreement made by the notary in Kudus in short peneitian conducted interviews with Notary Agreement fiduciary explained that there was for their agreement in principal on the Agreement. Principal agreement on the fiduciary is a credit agreement. Once the creditor and the debtor makes a credit agreement the parties mengahadap competent authorities make authentic act is the Notary. Its basic principle agreement, a notary can make Fiduciary Warranty Agreement. ${ }^{13}$

In Kudus own both the debtor and creditor pair fiduciary Agreement to a notary public sometimes does not open. Besides the credit agreement made under the Agreement of hand, sometimes the debtor also follow the creditors. A Notary in carrying out its obligations create fiduciary Agreement must be carefully and cautiously. It is rare to find a Notary in a Agreement fiduciary deviated from the Act No. 42 of the fiduciary. But from interviews with the bank, to efisiensifitas Agreement in notary fees must be as effective as possible. So a fiduciary warranty Agreement after the Notary, the Agreement must be registered with the Directorate General of AHU online. But many parties are not mendaftarkanya for their costs incurred after registration.

\subsection{What Barriers And Solutions For Notary In Kudus In Practice The Implementation Of A Credit Agreement With A Fiduciary Warranty Agreement Has Made?}

Obstacles and barriers arising from a notary in Kudus in practice the implementation of a credit agreement with a fiduciary warranty Agreement he made would appear, if the penghadap dishonest to the Notary. ${ }^{14}$ The penghadap is meant here is the creditor and the debtor that entered into a credit agreement (the principal) and a pair of fiduciary warranty Agreement that is authentic to the Notary. Another obstacle that arises is the debt agreement between debtor and creditor accounts are created in the credit agreements do not yet have the nature of execution. The bank pair to the credit agreement to be made to the Notary Agreement accesoir that are eksecutorial rationale for creating additional certificate form fiduciary Agreement are to obtain legal certainty of execution if the debtor in perjanjianya are in default. Obstacles will arise if additional certificates in the form of fiduciary Agreement is not registered under the laws that govern them. These barriers in the form of additional costs arising from pendftaran to the Directorate General of Legal Administration public online. Since the number of certificates and lack of cost it could be a warranty Agreement that should not be registered in the register.

\footnotetext{
${ }^{13}$ Afandi Notary in Kudus personal interview dated 30-06-2018

${ }^{14}$ Afandi Notary in Kudus personal interview dated 30-06-2018
} 
The amount of traffic in the form of bank credit in the community who do pitang debt with collateral in the form of objects moving in the connective fiduciary Agreement, is good news for the world of Notary. But with many Agreement made by a Notary at a time, then the quantity HR (Human Resources) which is less in running a role can make a new problem. Therefore, to further facilitate efficiency and effectiveness, at the request of the parties facing, notary make any liking the penghadap. Heeding the law governing credit agreements and warranties fiduisa in this case is the Act No. 42 of 1999 on the fiduciary, may result in a disadvantage for anyone involved in it.

A solution that can solve the constraints faced by the notary is a Notary as a state official must always obey and keep the rules in manjalankan jabatanya. The rules that apply to the Notary namely Law Notary. Always be careful in carrying out the obligations and responsibilities as a Notary Public. By always adhering to the Civil Code and UUJN and laws that make basic fiduciary Agreement (Act no 42 th 1999).

\section{Closing}

\subsection{Conclusion}

- The implementation of Act No. 42 of 1999 on Fiduciary Notary in Kudus associated with fiduciary Agreement not all in accordance with the rules that govern them. Found some creditors pair fiduciary to the Notary Agreement but the creditor the grounds of efficiency funds, the Agreement is not registered.

- Barriers and obstacles for Notaries in running his position in this case is a Agreement fiduciary in Kudus encountered several obstacles. The number of certificates must be made by a notary at a time, then some rules such as not heed daftarkanya fiduciary Agreement, so that in case of default the idak assurance can be executed. Lack of understanding of the Notary Public Act No.42 of 1999 on Fiduciary.

\subsection{Suggestion}

- In making the notary Agreement either authentic or under the arm. Notaries must be responsible for formally in every Agreement he had done, so that the Agreement has the authentic nature referred to in Article 1868 Civil Code.In performing its duties, the notary must bepedoman the Scriptures Civil (Civil Code), Act of Notary (UUJN 2014), as well as the code of conduct notary (Article 82, paragraph 2 UUJN 2014), While the fiduciary Agreement, the notary must also be guided by the Act No. 42 of 1999 on Fiduciary. A Notary in running peranya as a state official who makes authentic evidence should not benefit one party. Besides the notary must be neutral,honest, independent impartial, because the notary representing two (2) parties and the notary is also not a party among the parties in the agreement.

- Need for a prudential and ketelian when creating a fiduciary warranty Agreement. The task is not only assigned to a notary only. Notary Agreement only make it according to what is desired by the parties mengahadap. The parties are facing 
both society and the banking and finance should also participate in the making of the fiduciary warranty Agreement. The purpose of it all is the side facing recount the real thing, should not be a cover-up, not to be committing pretended, that the Agreement can be accounted for truth and does not harm the interests of the parties. If the public or penghadap dishonest, then Under Article 1365 of the Civil Code, if someone violated and bring harm to another person, then replace the loss

\section{References}

[1] Act No.2 of 2014 on the Amendment of Act No. 30 of 2004 concerning Notary.

[2] Actof the Republic of Indonesia No.7 of 1992 on Banking as amended by Act No. 10 of 1998.

[3] Afandi Notary in Kudus personal interview dated 30-06-2018

[4] Djuhaenah Hasan 1996 Lembaga Jaminan Kebendaan Bagi Tanah dan Benda Lain Yang Melekat Pada Tanah Dalam Konsepsi Penerapan Asas Pemisahan Horizontal (Suatu Konsep Dalam Menyongsong Lahirnya Lembaga Hak Tanggungan) (Bandung: Citra Aditya Bakti).

[5] Gunawan Widjaja and Ahmad Yani 2003 Jaminan Fidusia PT. Rajawali Press Jakarta.

[6] H. Salim HS 2007 Perkembangan Hukum Jaminan Di Indonesia Jakarta: Raja Grafindo Persada.

[7] Hermansyah 2006 Hukum Perbankan Nasional Indonesia Prenada Media Group Jakarta.

[8] Law of the Republic of Indonesia (Act) No. 42 of 1999 (42/1999) About Fiduciary.

[9] Law On Notary UU no. 30 LN No. 1172004 TLN No. 4432.

[10] Malay SP Hasibuan 2006 Dasar-dasar Perbankan Bumi Pustaka Jakarta.

[11]Patrik Purwahid and Kashadi 2009 Hukum Jaminan Semarang BP Undip.

[12] Rini Pamungkasih 2009101 Draf Surat Perjanjian Mediatama Yogyakarta.

[13]Soerjono Soekamto 1982 Pengantar Penelitian Hukum UI Jakarta. 